\title{
Wild boar: an increasing concern for Aujeszky's disease control in pigs?
}

\author{
Mariana Boadella*, Christian Gortázar, Joaquín Vicente and Francisco Ruiz-Fons
}

\begin{abstract}
Background: The goal of this study was describing the temporal evolution of Aujeszky's disease virus (ADV) contact prevalence among Eurasian wild boar (Sus scrofa) populations under different management regimes and contact likelihoods with domestic pigs. Given the recent increase in wild boar abundance throughout Europe, we hypothesized that wild boar contact with ADV would remain stable in time even after significant reduction of ADV prevalence in domestic pigs.

Results: Sera from 1659 wild boar were collected from 2000 to 2010 within 6 areas of the Iberian Peninsula and tested for the presence of antibodies against ADV by ELISA. According to sampling date, wild boar were grouped into three time periods. ADV prevalence was compared through period both globally and by geographic area. Overall seroprevalence for the ten-year study period was $49.6 \pm 2.4 \%$. The highest seroprevalence was recorded in areas with intense wild boar management. The annual proportion of positive wild boar sampling sites remained stable through the study period, while the percentage of domestic pig AD positive counties decreased from $70 \%$ in 2003 to $1.7 \%$ in 2010.
\end{abstract}

Conclusions: Results presented herein confirmed our hypothesis that ADV would remain almost stable in wild boar populations. This evidences the increasing risk wild boar pose in the final stages of ADV eradication in pigs and for wildlife conservation.

Keywords: Disease control, Monitoring, Pseudorabies, Seroprevalence, Sus scrofa, Wildlife

\section{Background}

Aujeszky's disease (AD), also known as pseudorabies, is one of the most economically important infectious diseases of swine for which suids are the natural hosts [1]. The disease is caused by Suid herpesvirus type I, a neuroinvasive virus with a wide host range that excludes only higher primates. Mammals other than suids are considered dead-end hosts since infection is normally fatal before virus excretion occurs. AD has a high economic impact in pig husbandry, both through direct effects of the disease on the animals and through movement and trade restrictions of pigs and their products. The direct impact of $\mathrm{AD}$ in wild boar population dynamics is considered to be low, but AD outbreaks with associated wild boar mortality have been reported and restrictions to wild boar movements may also have an impact on wild boar production for hunting $[2,3]$.

\footnotetext{
* Correspondence: mariana.boadella@gmail.com

IREC (CSIC-UCLM-JCCM), Ronda de Toledo s/n, Ciudad Real, Spain
}

Implications in conservation are considerable since fatal cases have repeatedly been described in endangered carnivores after consumption of ADV contaminated meat $[4,5]$. In the Iberian Peninsula, the Iberian wolf (Canis lupus signatus) uses Eurasian wild boar (Sus scrofa, the ancestor of the domestic pig) as an important part of the diet [6]. From the literature reviewed, to date ADV infection has not been reported in wolves even though fatal cases do occur in hunting dogs [7]. Moreover, other endangered carnivores such as the brown bear (Ursus arctos) and the Iberian lynx (Lynx pardinus) do occasionally consume wild boar among their prey or carrion species $[8,9]$, and thus may also be at risk of ADV infection (e.g. fatal ADV reports in brown bears $[5,10]$ ).

Wildlife can act as reservoirs for pathogens shared with their related domestic species, being able to transmit and maintain them even without the presence of the domestic reservoir [11]. The wild boar-domestic pig interface represents one of the clearest examples of this scenario, as both species have a mutual transmission
C Biomed Central

(C) 2012 Boadella et al; licensee BioMed Central Ltd. This is an Open Access article distributed under the terms of the Creative Commons Attribution License (http://creativecommons.org/licenses/by/2.0), which permits unrestricted use, distribution, and reproduction in any medium, provided the original work is properly cited. 
risk for their infectious and parasitic diseases [2,12]. As disease eradication programs are implemented in the domestic species, wildlife reservoirs should be considered for the program success since they come to be increasingly important [13].

In many parts of the world, efforts are being carried out to control ADV in domestic pigs. In Europe, most countries (including Spain) have implemented strict national eradication programs based on initial large scale vaccination of pigs with attenuated glycoprotein $\mathrm{E}$ (gE)-deleted vaccines. In countries that have reached the AD-free status, vaccination against ADV is forbidden [14]. But despite the efforts and subsequent success on AD eradication in domestic pigs, the disease is being continuously reported in wild boar populations. For instance, Germany achieved the AD-free status in 2003 despite the increasing seroprevalences (from $0.4 \%$ in 1985 to $16.5 \%$ in 2008 ) and widespread AD distribution in wild boar $[14,15]$. In France, occasional outbreaks have been described in outdoor pig farms, where contact with wild boar was deemed as the origin $[16,17]$. ADV contact prevalence in wild boar has also been recorded in several other European countries, such as Spain $(0.8-44 \%[18,19])$, France (3.5\% [20]), Italy (30-51\% [21,22]), Switzerland (2.8\% [23]), Croatia (55\% [24]), Slovenia (31\% [25]), Poland (11\% [26]) and Russia (32\% [27]); suggesting that ADV may be endemic in most of these wild boar populations. In contrast, countries with limited wild boar populations such as Netherlands, or Sweden with recently expanding wild boar populations, do not record ADV in wild boar [28,29].

In Spain, the national AD eradication scheme started in 1995 (Royal Decree [RD] 245/1995) [30]. The main control measures were compulsory vaccination with gE negative vaccines, movement restriction and serological testing. The AD eradication program was reinforced in 2003 (RD $427 / 2003$ ) and subsequently in recent years by applying tighter animal movement restrictions and more intensive serological testing and vaccination [31]. The AD eradication program has led to a considerable reduction of ADV prevalences in domestic pigs, although eradication in the whole territory has not yet been achieved [30].

The wild boar is the most widespread and generally also the most abundant wild ungulate in large portions of the Iberian Peninsula. Wild boar populations are continuously expanding numerically and geographically [32,33]. Furthermore, in some areas of the south-central Iberian Peninsula, wild boar are part of a growing hunting industry where management practices, such as high-wire fencing, artificial feeding and restocking are on the rise [32]. At the same time, sanitary measures for wildlife are not being implemented to match this development. As a result, high wild boar densities have already been shown to be a risk factor with negative consequences for the control of AD and other infectious diseases [34-37].
Although for ADV it has been shown that the prevalence in wild boar populations was not a significant risk factor for the level of AD prevalence in the coexisting pig farms [37], there are studies that suggest the opposite [38]. Moreover, the experimental infection of domestic pigs with ADV strains of wild boar origin [39] and the excretion of virus to the environment by wild boar $[40,41]$, suggest the possibility of ADV transmission between both suids.

The goal of this study was describing the temporal evolution of ADV contact prevalence among wild boar populations under different management regimes and varying contact with pigs in Spain. Based on the European literature, we hypothesized that wild boar contact with ADV would remain stable in time even after significant reduction of ADV prevalence in domestic pigs.

\section{Results}

The overall seroprevalence for the ten-year study period was $49.6 \pm 2.4 \%$ (S.E. at 95\% CI), (Rogan-Gladen correction $[\mathrm{RGC}]: 50.7 \pm 2.4)$. Antibody prevalences were high in all areas except for AS (7.5 $\pm 4.4 \%$ [RGC: $4.9 \pm 3.7 \%$ ]) and TO $(11 \pm 6.4 \%$ [RGC: $8.7 \pm 5.8 \%])$. Figure 1 shows the observed prevalences by area in the three sampling periods. The highest mean seroprevalences were recorded in areas where intense wild boar management was present: MT $(61.4 \pm 3.4 \%$ [RGC: $63.5 \pm 3.4 \%])$ and SM (54.6 \pm 5.1\% [RGC: $56.1 \pm 5.1 \%]$ ).

In three areas the observed increase in seroprevalence was statistically significant (IBER, TO and SM), while in MT the seroprevalence decreased (Chi-square, $\mathrm{p}<0.005$ in all cases). In TO area, ADV contact appeared for the first time in the period 2004-2007 (12.3 \pm 8.5\% [RGC: $10.1 \pm$ $7.8 \%]$ ) and increased in the following period (Figure 1).

The annual proportion of individual sampling sites with at least one seropositive wild boar remained stable during the ten-year period, while the percentage of domestic pig AD positive counties decreased from $70 \%$ in 2003 to $1.7 \%$ in 2010 (Figure 2).

In one specific study site in northern Spain, outside the range of the main high prevalence areas, ADV seropositivity was first detected in 2008 in 27 out of 48 sampled wild boar (56.3 $\pm 14 \%$ [RGC: $57.9 \pm 14 \%])$. The estimated level of confidence for the negative results in the preceding period 2003-2007 (none out of 12) was 95\% for an expected prevalence of $20 \%$. Wild boar censusing confirmed a marked increase in abundance and spatial aggregation between both time periods (Figure 3 ).

\section{Discussion}

Results presented here confirmed our hypothesis that ADV would remain almost stable in wild boar populations. This occurred in those areas where wild boar production as a hunting resource is practiced, and ADV 

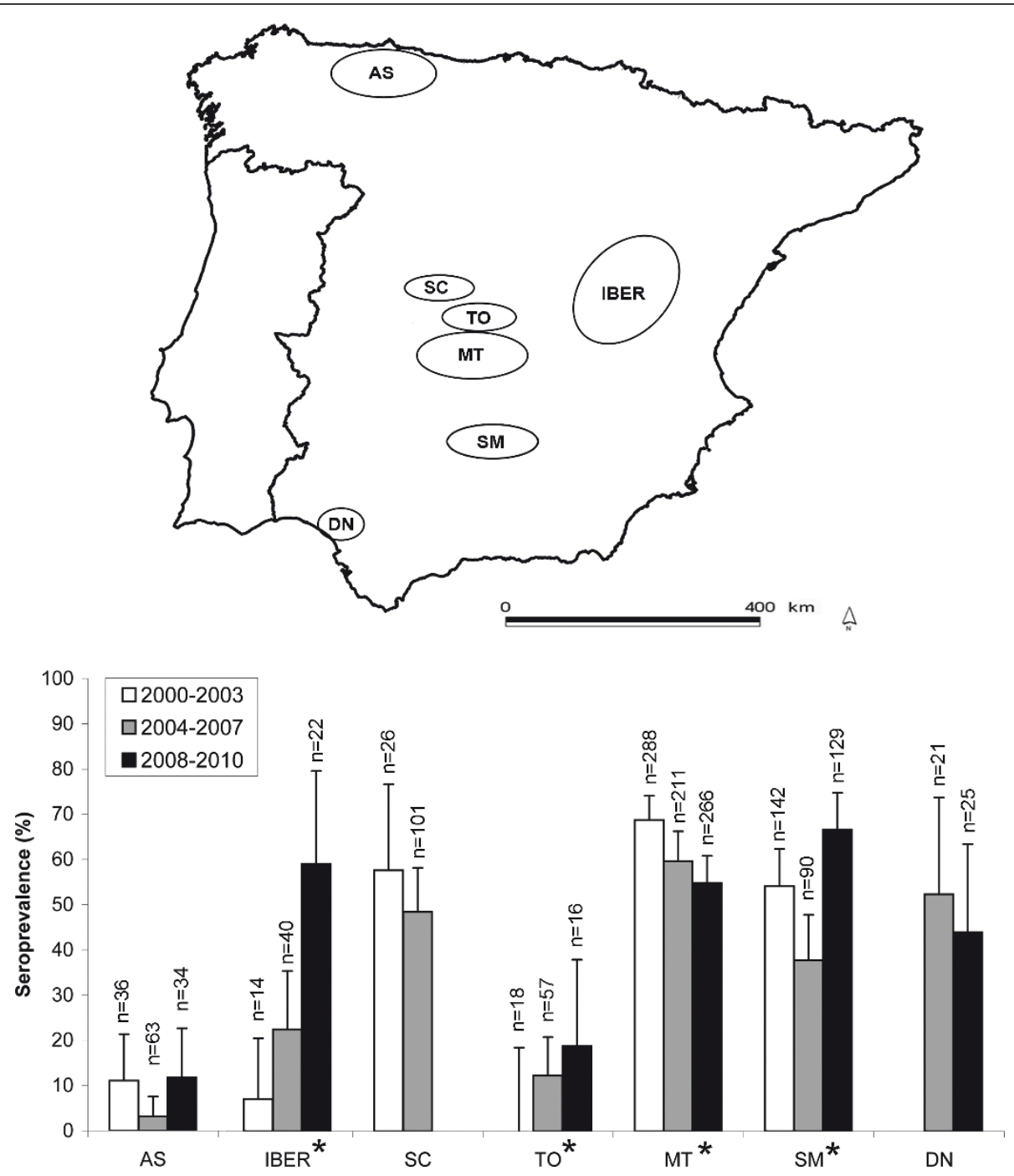

Figure 1 Sampled areas and Aujeszky's disease virus (ADV) seroprevalences. Map of the Iberian Peninsula showing the six sampled areas for the study (upper panel). Seroprevalences (and associated 95\% standard errors) for each area during the three considered seasons (2000-2003, 2004-2007, 2008-2010) are shown in the lower panel. Within each area, significant differences in overall season seroprevalence are marked with an asterisk.

seroprevalences are high. Results also showed increasing seroprevalence rates for some of the studied areas in spite of the decreasing trend reported in pigs. Time trends in wild boar contact with ADV were independent of the area's likelihood of contact with pigs, adding evidence to the hypothesis of that AD maintenance in wild boar is independent of the pig situation $[14,37,41]$.

Sample sizes per individual site were small. This motivated studying representative areas for wild boar distribution and management characteristics in Spain. The limited sample size also means that results, particularly regarding time trends by area, need to be taken with caution. However, total wild boar ADV seroprevalence clearly remained stable after ten years, confirming that $\mathrm{AD}$ remains endemic at high prevalences in the south- central Spanish wild boar populations [18,37]. This finding is in compliance with other studies that record stable or even increasing trends of ADV contact in different wild boar and feral pig populations $[14,15,20,42]$. In our area, wild boar density and spatial aggregation within fenced hunting areas have been previously identified as risk factors for wild boar ADV contact prevalence $[35,37]$. These factors have not changed during the studied period. Thus, in the absence of any control measure and considering the ability of ADV to remain latent in infected suids [43], ADV prevalences were not expected to decline. Prevalences recorded in areas with intense management are among the highest of the literature worldwide [1]. Thus, the observed time trends in these prevalences (decrease in MT and increase in SM) 


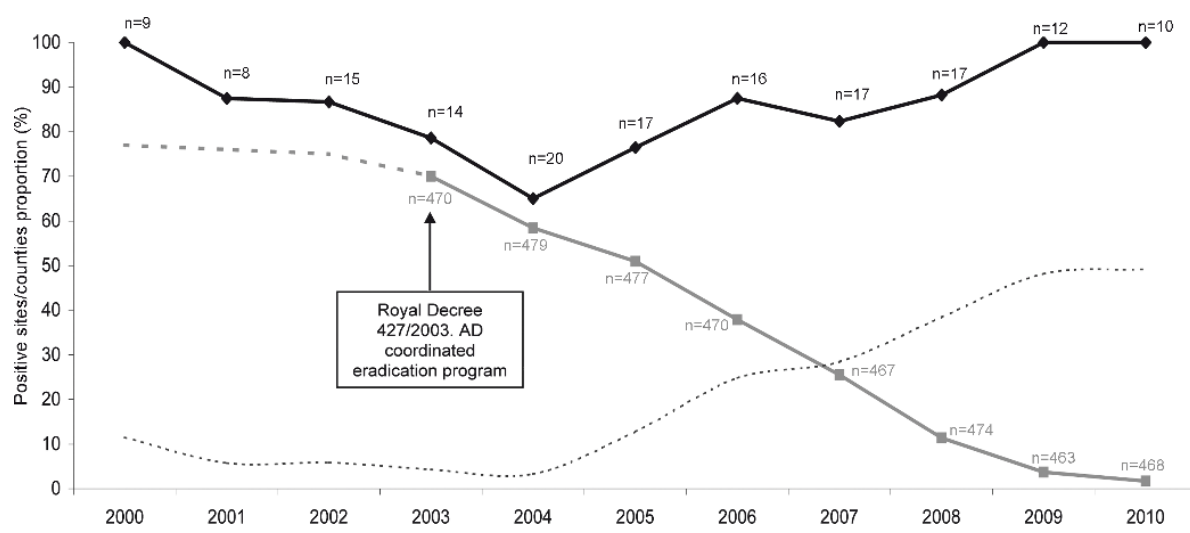

Figure 2 Temporal trends on Aujeszky's disease virus (ADV) seroprevalences in wild boar and pig. Time trend (2000-2010) of the annual proportion of sampling sites with seropositive wild boar (black diamonds), and of the proportion of counties in Spain with ADV in domestic pig (grey squares; based on data from the Spanish Ministry of the Environment and Rural and Marine Affairs, MARM). Numbers on the black line indicate the number of wild boar sampling sites per year. Numbers in grey indicate the number of reported counties per year. The discontinuous grey line is an estimated prevalence of positive counties before 2003 as data were not available before this date. The dotted line represents the hypothetical relative risk of ADV spill-back from wild boar to domestic pig, based on the difference between the pig and wild boar ADV proportions.

may represent cyclic fluctuations around a "steady state" that ADV seroprevalence may have reached under these particular conditions. Even though wild boar population characteristics are different, a similar dynamic situation has also been proposed to be occurring in wild boar ADV high-prevalence areas of Germany [1]. This asymptote seems not to have been reached in other Spanish wild boar populations. Furthermore, intense hunting management practices are becoming popular in certain areas outside south-central Spain. This might suggest that higher prevalences will be reached as the wild boar population increases and the management becomes more intense.

The specific case illustrated in Figure 3 is an example of the effect of intense wild boar management for

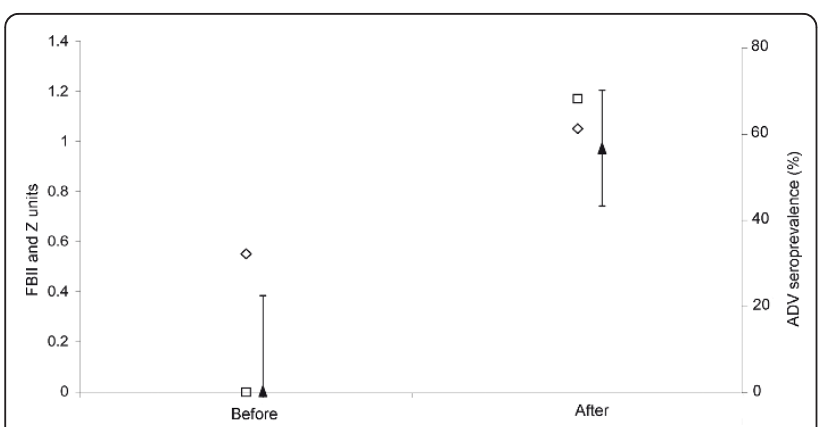

Figure 3 Aujeszky's disease virus (ADV) seroprevalence and wild boar relative abundance and spatial aggregation changes in a private hunting estate. Wild boar relative abundance (FBII; diamonds), aggregation index (Z; squares), and ADV seroprevalence (black triangles, 95\% Cl) in an estate where wild boar management drastically changed during the study period. hunting on the temporal trend of ADV seroprevalence. Fencing and feeding led to a significant increase of wild boar abundance and aggregation [35], and to the detection of high contact prevalences with ADV (56\%). It is unlikely that a high ADV prevalence could have gone undetected in the preceding period. Therefore, based on the current and previous observations [18], we suggest that the emergence of ADV seroprevalence could be boosted by intense hunting management practices, including a possible translocation of wild boar from positive sites. As suggested for tuberculosis, efforts should be done to control the proliferation of such intense game management without sanitary control in disease-free areas, since they can become risk hotspots with negative implications for animal health and for conservation [44].

In contrast and despite of the situation in the studied wild boar populations, ADV seroprevalence in Spanish domestic pigs experienced a significant reduction, thus showing that the eradication efforts were successful. A comprehensive study of European ADV isolates of wild boar origin, including Spanish ones, demonstrated that all except one belonged to genotype I [45]. Based on the observation that mainly type II strains were found in domestic pigs in Central Europe, it has been suggested that infections of wild boar by domestic pigs did not occur recently [1]. Hence, spill over between pigs and wild boar is apparently not a frequent event. However, the pig vaccination campaigns probably had a main role in this decrease of ADV, but we open the question of which will be the situation if Spain reaches the ADVfree status and pig vaccination is no longer permitted? Outdoor pig production is an environmentally friendly and sustainable productive system that additionally 
improves animal welfare and product quality, aspects that are increasingly demanded by the European society. These added values of outdoor production carry nonetheless a sanitary risk because of the increased probability of interactions with wild boar and other wildlife of uncontrolled sanitary status. There are several examples in the literature about the link between open-air or back-yard pig production and the risk of disease transmission at the pig-wild boar interface (Classical Swine Fever in Germany [46]; African swine fever in Sardinia [47] and the Caucasus [48], and ADV in France [16]). Thus, when pig biosafety measures are insufficient to avoid contact with wild boar, the wild boar could become a risk for ADV re-introduction [23]. If wild boar are seen as a source of the disease, a potential conflict on biosafety can arise between the pig industry and hunting land owners $[37,49]$. Because of the huge difficulties in controlling ADV in free-roaming wild boar, the main recommendation to maintain ADV-free openair produced domestic pigs would be not to stop vaccination. Nonetheless, in countries without vaccination such as Switzerland, it has been advised to include outdoor pigs in areas at risk in routine wild boar ADV surveillance programs, since transmission between infected wild boar and outdoor pigs might occur in the future [23]. In parallel, it is important to drive efforts towards improved pig biosafety [50], along with continuous monitoring of the wild boar AD epidemiological situation (e.g. the recent establishment of the Spanish National Wildlife Disease Surveillance Scheme [51]). Eventually, research on means to control ADV in wild boar could be pertinent [52].

In the Iberian Peninsula, the presence of ADV in wild boar also exposes endangered wild carnivores to the risk of contracting lethal infection [53]. ADV contact has been detected in wild boar in protected areas where they coexist with endangered carnivores (bear and wolf in AS, wolf in IBER, wolf and lynx in SM, lynx in DN). This adds interest to ADV regarding conservation. Unfortunately, conservation programs often underestimate the role that wildlife diseases can play in their success [54].

\section{Conclusions}

With the presented scenario, where wildlife populations represent a potential sanitary risk for livestock, transdisciplinary wildlife disease research may provide an opportunity for stakeholders to reconsider the current approach of disease eradication in livestock towards a less severe but more sustainable concept of disease control, at least for open-air systems.

\section{Methods}

\section{Wild boar sampling}

A total of 1659 serum samples collected between 2000 and 2010 from beating or Monteria hunter-harvested wild boar, were selected for this retrospective study. Monteria hunting of wild boar is random and thus, is accepted as a random survey method for wild boar [55]. The selected sample was stratified by sex and age classes. Sex was known for 1503 animals and included 687 males and 816 females. Age classes of biological meaning included juveniles $(\mathrm{n}=316)$, yearlings $(\mathrm{n}=464)$, and adults $(\mathrm{n}=733)$, as described in previous studies [56] and in Sáenz de Buruaga et al. (1991) [57]. Sera selected for this study had gone through less than five freeze-thaw cycles and severely haemolysed samples were excluded [58].

Samples came from 37 sites (range 5 to 111 samples per site) and were grouped into six geographic areas of biological meaning (Table 1; Figure 1) plus an isolated fenced estate (not shown in Figure 1). The selected areas are representative of a gradient of situations from an intense hunting management (involving fencing, artificial feeding and watering) to a lesser or inexistent hunting management. More precise descriptions of these areas have been given by [56]. One area (SM) is part of the geographical range of Iberian pig production,

Table 1 Sample size and wild boar population characteristics of the 6 study areas.

\begin{tabular}{ccccc}
\hline Area & $\begin{array}{c}\text { Number wild boar } \\
\text { sampled }\end{array}$ & $\begin{array}{c}\text { Wild boar } \\
\text { density }\end{array}$ & $\begin{array}{c}\text { Wild boar } \\
\text { management }\end{array}$ & $\begin{array}{c}\text { Likelihood of contact with open air raised } \\
\text { domestic pigs }\end{array}$ \\
\hline Asturias (AS) & 133 & Medium & Low or inexistent & Low \\
$\begin{array}{c}\text { Sistema Central (SC) } \\
\text { Sistema Ibérico }\end{array}$ & 127 & Medium & Low or inexistent & Low \\
(IBER) & 76 & Low & Low or inexistent & Low \\
Toledo (TO) & 91 & Low & Low or inexistent & Low \\
$\begin{array}{c}\text { Montes de Toledo } \\
\text { (MT) }\end{array}$ & 765 & High & Frequently intense & High [62] \\
Sierra Morena (SM) & 361 & High & Frequently intense & Low \\
Doñana (DN) & 46 & Medium-high & Inexistent & \\
\hline
\end{tabular}

Number of sampled wild boar, categorized wild boar density (low, medium, high), wild boar management (inexistent to intense) and likelihood of contact with open air raised domestic pigs (low, medium, high) generally present in each of the six areas of the study, mainly based on observational data from the authors (unpublished results). 
a traditional breed that is reared by open air farming or as backyard production (Table 1).

In order to analyze prevalence changes in time, samples were grouped by area into three periods: years 2000-2003, 2004-2007 and 2008-2010. We also used the annual proportion of positive sampling sites to compare with pig data on positive counties (Figure 2).

In one private hunting estate outside the described areas, we recorded wild boar relative abundance (FBII) and aggregation index (Z) in 2002 and 2010, as described in previous studies $[35,56]$. ADV seroprevalence was calculated for wild boar sampled in 2003-2005 $(\mathrm{n}=12)$ and in 2008-2010 ( $\mathrm{n}=48)$. Wild boar management started to change late in 2005 through improved fencing and supplementary feeding.

\section{ELISA test}

A commercially available blocking ELISA was used for screening of antibodies to ADV in accordance with the manufacturers' instructions (IDEXX HerdCheck AntiADV gpI, IDEXX, Inc., USA). This ELISA technique has been broadly used in wild boar [14,18,59] and for domestic pigs it has a sensitivity of $95-98 \%$ and a specificity of $97-99 \%$ according to the manufacturer.

\section{Data on pig status}

ADV seroprevalence data of the control and eradication campaign in Spain at county level from 2003 to 2010 were available from the Spanish Ministry of the Environment and Rural and Marine Affairs [30]. With the data provided, we calculated the annual proportion of positive counties.

\section{Statistics}

Standard errors at $95 \%$ confidence intervals were calculated for apparent prevalences. Mean prevalence estimates were adjusted for test sensitivity and the specificity using Rogan-Gladen corrections (RGC). RGC were calculated using the lowest values of ELISA sensitivity and specificity given by the manufacturer, $95 \%$ sensitivity-97\% specificity [60]. ADV prevalences were compared through period both globally and by geographic area by means of chi-square tests. The p-value was set at 0.05. Data was analyzed using the IBM SPSS statistical package, version 19.0 (IBM Corporation, Somers, NY, USA). WinEpiscope software [61] was used to calculate the level of confidence for negative results.

\section{Acknowledgements}

The current study is a contribution to JCCM PPIC10-0226-0243 and FAU2008-00004-C03 INIA. F. Ruiz-Fons is supported by the Spanish National Research Council (CSIC). Studies on diseases shared between domestic animals and wildlife are also supported by Santander and Fundación Marcelino Botín. We thank Paqui Talavera and all the colleagues at IREC that participated in the field work, collecting and processing all the samples and making this research possible.

\section{Authors' contributions}

$M B, C G, J V$ and FRF conceived and designed the study. MB and FRF carried out the laboratory work. MB, CG, JV and FRF participated in sampling and field work. MB and FRF analyzed the data. All authors participated in drafting the manuscript. All authors have read and approved the final manuscript.

\section{Conflict of interest statement}

The authors declare that they have no competing interests.

Received: 19 August 2011 Accepted: 17 January 2012

Published: 17 January 2012

\section{References}

1. Müller T, Hahn E, Tottewitz F, Kramer M, Klupp B, Mettenleiter T, Freuling C: Pseudorabies virus in wild swine: a global perspective. Arch Virol 2011, 156:1691-1705.

2. Ruiz-Fons F, Segalés J, Gortázar C: A review of viral diseases of the European wild boar: effects of population dynamics and reservoir role. Vet J 2008, 176:158-169.

3. Gortazar C, Vicente J, Fierro Y, Leon L, Cubero MJ, Gonzalez M: Natural Aujeszky's disease in a Spanish wild boar population. In Domestic Animal Wildlife Interface: Issue for Disease Control, Conservation, Sustainable Food Production, and Emerging Diseases. Volume 969. Edited by: Gibbs EPJ, Bokma BH. New York: New York Acad Sciences; 2002:210-212.

4. Glass CM, McLean RG, Katz JB, Maehr DS, Cropp CB, Kirk LJ, McKeirnan AJ, Evermann JF: Isolation of pseudorabies (Aujeszky's disease) virus from a Florida panther. J Wildl Dis 1994, 30:180-184.

5. Zanin E, Capua I, Casaccia C, Zuin A, Moresco A: Isolation and characterization of Aujeszky's disease virus in captive brown bears from Italy. J Wildl Dis 1997, 33:632-634.

6. Barja I: Prey and prey-age preference by the Iberian wolf Canis lupus signatus in a multiple-prey ecosystem. Wild Biol 2009, 15:147-154.

7. Cay $A B$, Letellier C: Isolation of Aujeszky's disease virus from two hunting dogs in belgium after hunting wild boars. Vlaams Diergeneeskundig Tijdschrift 2009, 78:194-195.

8. Blanco JC, Ballesteros F, García-Serrano A, Herrero J, Nores C, Palomero G: Behaviour of brown bears killing wild ungulates in the Cantabrian Mountains, Southwestern Europe. Eur J Wildl Res 2011, 57:669-673.

9. Valverde JA: Estructura de una comunidad mediterránea de vertebrados terrestres. Doñana Acta Vertebrata 1967, 1:1-129.

10. Banks M, Monsalve Torraca LS, Greenwood AG, Taylor DC: Aujeszky's disease in captive bears. Vet Rec 1999, 145:362-365.

11. Gortazar C, Ferroglio E, Hofle U, Frolich K, Vicente J: Diseases shared between wildlife and livestock: a European perspective. Eur J Wildl Res 2007, 53:241-256.

12. Meng XJ, Lindsay DS: Wild boars as sources for infectious diseases in livestock and humans. Philos Trans R Soc Lond B Biol Sci 2009, 364:2697-2707.

13. Müller T, Conraths FJ, Hahn EC: Pseudorabies virus infection (Aujeszky's disease) in wild swine. Infect Dis Rev 2000, 2:27-34

14. Pannwitz G, Freuling C, Denzin N, Schaarschmidt U, Nieper H, Hlinak A, Burkhardt S, Klopries M, Dedek J, Hoffmann L, Kramer M, Selhorst T, Conraths FJ, Mettenleiter T, Müller T: A long-term serological survey on Aujeszky's disease virus infections in wild boar in East Germany. Epidemiol Infect 2012, 140:348-358.

15. Lutz W, Junghans D, Schmitz D, Müller T: A long-term survey of pseudorabies virus infections in European wild boar of western Germany. Zeitschrift Fur Jagdwissenschaft 2003, 49:130-140.

16. Hars J, Rossi S: Actualites dans le domaine de la surveillance des maladies transmissibles en France (peste porcine classique, maladie d'Aujeszky, tuberculose, brucellose, leptospirose, trichinellose, influenza aviaire, virus West Nile). Proceedings of the 23èmes Recontres du GEEFSM; May 27 to 29 La Cortinada, Andorre; 2005.

17. Event summary: Aujeszky's disease, France. [http://web.oie.int/wahis/ public.php?page=event_summary\&reportid=9703].

18. Vicente J, Ruiz-Fons F, Vidal D, Hofle U, Acevedo P, Villanua D, FernandezDe-Mera IG, Martin MP, Gortazar C: Serosurvey of Aujeszky's disease virus infection in European wild boar in Spain. Vet Rec 2005, 156:408-412. 
19. Closa-Sebastià F, Casas-Díaz E, Cuenca R, Lavín S, Mentaberre G, Marco I: Antibodies to selected pathogens in wild boar (Sus scrofa) from Catalonia (NE Spain). Eur J Wildl Res 2011, 57:977-981.

20. Albina $E$, Mesplède $A$, Chenut $G$, Le Potier MF, Bourbao G, Le Gal S, Leforban Y: A serological survey on classical swine fever (CSF), Aujeszky's disease $(A D)$ and porcine reproductive and respiratory syndrome (PRRS) virus infections in French wild boars from 1991 to 1998. Vet Microbiol 2000, 77:43-57.

21. Montagnaro S, Sasso S, De Martino L, Longo M, Lovane V, Ghlurmino G, Plsanelli G, Nava D, Baldl L, Pagninl U: Prevalence of antibodies to selected viral and bacterial pathogens in wild boar (Sus scrofa) in Campania Region, Italy. J Wildl Dis 2010, 46:316-319.

22. Lari A, Lorenzi D, Nigrelli D, Brocchi E, Faccini S, Poli A: Pseudorabies virus in European wild boar from Central Italy. J Wildl Dis 2006, 42:319-324.

23. Köppel C, Knopf L, Ryser MP, Miserez R, Thür B, Stärk KDC: Serosurveillance for selected infectious disease agents in wild boars (Sus scrofa) and outdoor pigs in Switzerland. Eur J Wildl Res 2007, 53:212-220.

24. Zupancic Z, Jukic B, Lojkic M, Cac Z, Jemersic L, Staresina V: Prevalence of antibodies to classical swine fever, Aujeszky's disease, porcine reproductive and respiratory syndrome, and bovine viral diarrhoea viruses in wild boars in Croatia. J Vet Med Ser B 2002, 49:253-256.

25. Vengust $G$, Valencak $Z$, Bidovec A: A serological survey of selected pathogens in wild boar in Slovenia. J Vet Med Ser B-Infect Dis Vet Public Health 2006, 53:24-27.

26. Szweda W, Lipowski A, Ciecierski H, Zalewski K, Pirus T: European wild boar (Sus scrofa L.) as a reservoir of Herpesvirus suis 1. Medycyna Weterynaryjna 1998, 54:541-544.

27. Kukushkin S, Baborenko E, Baybikov T, Mikhalishin V, Domskiy I: Seroprevalence of antibodies to main porcine infectious pathogens in wild boar in some regions of Russia. Acta Silvatica et Lignaria Hungarica 2009, 5:147-152.

28. Elbers ARW, Dekkers LJM, Van Der Giessen JWB: Sero-surveillance of wild boar in the Netherlands, 1996-1999. OIE Rev Sci Tech 2000, 19:848-854.

29. Surveillance of zoonotic and other animal disease agents in Sweden 2009. [http://www.sva.se/upload/pdf/Tj\%C3\%A4nster\%20och\%20produkter/ Trycksaker/Surveillance2009.pdf].

30. Reports on Spanish sanitary programs. [http://rasve.mapa.es/Publica/ Sanidad/sitnat.asp]

31. Allepuz A, Saez M, Solymosi N, Napp S, Casal J: The role of spatial factors in the success of an Aujeszky's disease eradication programme in a high pig density area (Northeast Spain, 2003-2007). Prev Vet Med 2009, 91:153-160.

32. Acevedo P, Escudero MA, Muñoz R, Gortazar C: Factors affecting wild boar abundance across an environmental gradient in Spain. Acta Theriol 2006, 51:327-336.

33. Gortazar C, Herrero J, Villafuerte R, Marco J: Historical examination of the status of large mammals in Aragon, Spain. Mammalia 2000, 64:411-422.

34. Gortazar C, Acevedo P, Ruiz-Fons F, Vicente J: Disease risks and overabundance of game species. Eur J Wildl Res 2006, 52:81-87.

35. Acevedo P, Vicente J, Hofle U, Cassinello J, Ruiz-Fons F, Gortazar C: Estimation of European wild boar relative abundance and aggregation: a novel method in epidemiological risk assessment. Epidemiol Infect 2007, 135:519-527.

36. Vicente J, Hofle U, Garrido JM, Fernandez-de-Mera IG, Acevedo P, Juste R, Barral M, Gortazar C: Risk factors associated with the prevalence of tuberculosis-like lesions in fenced wild boar and red deer in south central Spain. Vet Res 2007, 38:451-464

37. Ruiz-Fons F, Vidal D, Vicente J, Acevedo P, Fernandez-de-Mera IG, Montoro V, Gortazar C: Epidemiological risk factors of Aujeszky's disease in wild boars (Sus scrofa) and domestic pigs in Spain. Eur J Wildl Res 2008, 54:549-555.

38. Corn JL, Cumbee JC, Barfoot R, Erickson GA: Pathogen exposure in feral swine populations geographically associated with high densities of transitional swine premises and commercial swine production. J Wildl Dis 2009, 45:713-721.

39. Müller TF, Teuffert J, Zellmer R, Conraths FJ: Experimental infection of European wild boars and domestic pigs with pseudorabies viruses with differing virulence. Am J Vet Res 2001, 62:252-258.

40. Ruiz-Fons F, Vidal D, Hofle U, Vicente J, Gortazar C: Aujeszky's disease virus infection patterns in European wild boar. Vet Microbiol 2007, 120:241-250.
41. Müller T, Teuffert J, Ziedler K, Possardt C, Kramer M, Staubach C, Conraths FJ: Pseudorabies in the European wild boar from Eastern Germany. J Wildl Dis 1998, 34:251-258.

42. Corn JL, Stallknecht DE, Mechlin NM, Luttrell MP, Fischer JR: Persistence of pseudorabies virus in feral swine populations. J Wildl Dis 2004, 40:307-310.

43. Alemañ N, Quiroga MI, Lopez-Pena M, Vazquez S, Guerrero FH, Nieto JM: Induction and inhibition of apoptosis by pseudorabies virus in the trigeminal ganglion during acute infection of swine. J Virol 2001, 75:469-479.

44. Boadella M, Acevedo P, Vicente J, Mentaberre G, Balseiro A, Arnal M, Martínez D, García-Bocanegra I, Casal C, Álvarez J, Oleaga Á, Lavín S, Muñoz M, Sáez-Llorente JL, de la Fuente J, Gortazar C: Spatio-temporal trends of Iberian wild boar contact with Mycobacterium tuberculosis complex detected by ELISA. EcoHealth, DOl: 10.1007/s10393-011-0713-y.

45. Müller T, Klupp BG, Freuling C, Hoffmann B, Mojcicz M, Capua I, Palfi V, Toma B, Lutz W, Ruiz-Fons F, Gortazar C, Hlinak A, Schaarschmidt U, Zimmer K, Conraths FJ, Hahn EC, Mettenleiter TC: Characterization of pseudorabies virus of wild boar origin from Europe. Epidemiol Infect 2010, 138:1590-1600.

46. Fritzemeier J, Teuffert J, Greiser-Wilke I, Staubach C, Schlüter H, Moennig V: Epidemiology of classical swine fever in Germany in the 1990s. Vet Microbiol 2000, 77:29-41.

47. Laddomada A, Patta C, Oggiano A, Caccia A, Ruiu A, Cossu P, Firinu A: Epidemiology of classical swine fever in Sardinia: a serological survey of wild boar and comparison with African swine fever. Vet Rec 1994, 134:183-187.

48. African swine fever in the Caucasus. [http://www.fao.org/docs/eims/ upload/242232/EW_caucasus_apr08.pdf].

49. Gortazar C, Ferroglio E, Lutton CE, Acevedo P: Disease-related conflicts in mammal conservation. Wildl Res 2010, 37:668-675.

50. Gortazar C, Vicente J, Boadella M, Ballesteros C, Galindo RC, Garrido J, Aranaz A, de la Fuente J: Progress in the control of bovine tuberculosis in Spanish wildlife. Vet Microbiol 2011, 151:170-178.

51. Spanish National Wildlife Disease Surveillance Scheme. [http://rasve. mapa.es/Publica/Programas/NORMATIVA\%20Y\%20PROGRAMAS\% 5CPROGRAMAS\%5CFAUNA\%20SILVESTRE\%5CPLAN\%20NACIONAL\%20DE\% 20VIGILANCIA\%20SANITARIA\%20EN\%20FAUNA\%20SILVESTRE_2011.PDF].

52. Ruiz-Fons F, Rodríguez O, Mateu E, Vidal D, Gortázar C: Antibody response of wild boar (Sus scrofa) piglets vaccinated against Aujeszky's disease virus. Vet Rec 2008, 162:484-485.

53. Capua I, Fico R, Banks M, Tamba M, Calzetta G: Isolation and characterisation of an Aujeszky's disease virus naturally infecting a wild boar (Sus scrofa). Vet Microbiol 1997, 55:141-146.

54. Leopold A: Game Management Madison, USA: Charles Scribner's Sons. Reprinted in 1986 by University of Wisconsin Press; 1933.

55. Fernández-Llario P, Mateos-Quesada P: Population structure of the wild boar (Sus scrofa) in two Mediterranean habitats in the western Iberian Peninsula. Folia Zool 2003, 52:143-148.

56. Vicente J, Segales J, Hofle U, Balasch M, Plana-Duran J, Domingo M, Gortazar C: Epidemiological study on porcine circovirus type 2 (PCV2) infection in the European wild boar (Sus scrofa). Vet Res 2004, 35:243-253.

57. Saenz de Buruaga M, Lucio AJ, Purroy FJ: Reconocimiento de sexo y edad en especies cinegéticas. 1 edition. Ediciones Leonesas SA; 1991.

58. Boadella M, Gortazar C: Effect of haemolysis and repeated freeze-thawing cycles on wild boar serum antibody testing by ELISA. BMC Research Notes 2011, 498

59. Ruiz-Fons F, Vicente J, Vidal D, Hofle U, Villanua D, Gauss C, Segales J, Almeria S, Montoro V, Gortazar C: Seroprevalence of six reproductive pathogens in European wild boar (Sus scrofa) from Spain: the effect on wild boar female reproductive performance. Theriogenology 2006, 65:731-743.

60. Rogan WJ, Gladen B: Estimating prevalence from the results of a screening test. Am J Epidemiol 1978, 107:71-76.

61. WinEpiscope program. [http://www.clive.ed.ac.uk/winepiscope]

62. Bech-Nielsen S, Fernandez J, Martinez-Pereda F, Espinosa J, Perez Bonilla Q Sanchez-Vizcaino JM: A case study of an outbreak of African swine fever in Spain. British Veterinary Journal 1995, 151:203-214.

doi:10.1186/1746-6148-8-7

Cite this article as: Boadella et al:: Wild boar: an increasing concern for Aujeszky's disease control in pigs? BMC Veterinary Research 2012 8:7. 